\title{
UJI TOKSISITAS EKSTRAK ETANOL UMBI TALAS (Colocasia esculenta L. Schoot ) DENGAN METODE BRINE SHRIMP LETHALITY TEST TERHADAP Artemia Salina Leach
}

\author{
Bayu Putra , Said Asrul Adjmi Assagaf
}

Fakultas Farmasi Universitas Muslim Indonesia Email : bayuputra.pharm@gmail.com.

\begin{abstract}
The research of toxicity assay of Ethanol Extracts of Taro tubers (Colocasia esculenta L. Schott) have been conducted with the aim of determining the effects of toxicity and anticancer potential of ethanol extract of tubers of taro (Colocasia esculenta L. Schott) by Brine Shrimp Lethality Test method against Artemia salina Leach. Ethanol extract, made with concentrations of 0.1, 1, 10, 100, 1000, and 10000 $\mu \mathrm{g} / \mathrm{ml}$ and for comparison with the drugs vincristine concentrations of 0.01, 0.1, 1 , and $10 \mu \mathrm{g} / \mathrm{ml}$. Negative control using sea water made with the same concentrations. Furthermore, each concentration $10 \mathrm{ml}$ of sea water and then put 10 shrimp larvae. The treatment is done by 10 replication at each concentration. Observations were made after 24 hours of treatment by counting the number of dead larva. The observations calculated using probit analysis program, showed LC50 values with $95 \%$ confidence level is 33,997 $\mu \mathrm{g} / \mathrm{ml}(7,970 \mu \mathrm{g} / \mathrm{ml}-151,231 \mu \mathrm{g} / \mathrm{ml})$. And the results of a comparison of data from drug vincristine showed $L C 50$ value is $0,398 \mu \mathrm{g} / \mathrm{ml}$ $(0,259 \mu \mathrm{g} / \mathrm{ml}-0,624 \mu \mathrm{g} / \mathrm{ml})$.
\end{abstract}

Key Words : Toxicity, Colocasia esculenta L.Schoot., Brine Shrimp Lethality Test.

\section{PENDAHULUAN}

Saat ini pemanfaatan tumbuhan obat untuk mengobati berbagai jenis penyakit semakin disukai masyarakat karena relatif jarang menimbulkan efek samping yang tidak diinginkan. Salah satu pemanfaatan yang signifikan adalah untuk terapi kanker. Penyakit kanker dikenal sebagai penyakit yang sukar disembuhkan dan dapat menyebabkan kematian bila telah mencapai stadium lanjut, sehingga merupakan masalah yang cukup sulit dalam bidang pengobatan. Walaupun telah cukup banyak ditemukan obat kemoterapi untuk pengobatan kanker, namun hasilnya belum memuaskan, karena disamping senyawa aktifnya kurang atau tidak selektif dalam membunuh sel-sel kanker, juga sering menimbulkan efek samping yang cukup besar. Kondisi seperti ini mendorong masyarakat melakukan 
Uji Toksisitas Ekstrak Etanol Umbi Talas (Colocasia esculenta L. Schoot) Dengan Metode Brine Shrimp Lethality Test Terhadap Artemia Salina Leach

pengobatan alternatif atau pun komplementer dengan menggunakan bahan alam atau obat tradisonal (Farida et al., 2010)

Salah satu tanaman obat yang digunakan untuk pengobatan kanker adalah tanaman talas (Colocasia esculenta L. Schott), familia araceae. Menurut Akmal (2009) Talas mengandung komponen makronutrien dan mikronutrien. Komponen mikronutrien yang terkandung dalam talas yaitu Vitamin $A$ ( $\beta$ - karoten) dan vitamin C. Beberapa penelitian menunjukkan bahwa makanan yang mengandung antioksidan (vitamin C dan $\beta$ - karoten) dapat mencegah penyakit diabetes melitus, rabun senja,dan berbagai penyakit kanker (Tungriani et al., 2012).

Salah satu langkah pertama untuk uji toksisitas ekstrak atau senyawa adalah dengan metode Brine Shrimp Lethality Test (BSLT). BSLT merupakan salah satu metode uji toksisitas yang banyak digunakan dalam penelusuran senyawa bioaktif yang bersifat toksik dari bahan alam. Metode ini dapat digunakan sebagai bioassayguided fractionation dari bahan alam karena mudah, cepat, dan murah. Beberapa senyawa bioaktif yang telah berhasil diisolasi dan dimonitor aktivitasnya dengan
BSLT menunjukkan adanya korelasi terhadap suatu uji spesifik antitumor.

Maksud dan tujuan dari penelitian ini adalah untuk menguji dan menentukan potensi toksisitas dan potensi antikanker pada ekstrak etanol umbi talas (Colocasia esculenta $L$. Schott) dengan metode BSLT (Brine Shrimp Lethality Test) terhadap Artemia salina Leach.

Berdasarkan uraian tersebut maka dilakukan peneltian mengenai uji toksisitas esktrak etanol umbi Talas (Colocasia esculenta L. Schott) dengan metode BSLT terhadap hewan uji Artemia salina Leach.

\section{METODE PENELITIAN}

\section{Jenis Penelitian}

$$
\text { Jenis penelitian yang }
$$

digunakan yaitu secara eksperimental, yang merupakan

penelitian laboratorium dengan menggunakan metode Brine Shrimp Lethality Test (BSLT).

\section{Waktu dan Lokasi Penelitian}

Penelitian ini dilakukan mulai bulan Maret 2014 sampai selesai di Laboratorium Farmakologi Fakultas Farmasi Universitas Muslim Indonesia Makassar.

\section{Alat dan Bahan digunakan}

Alat-alat yang akan dipakai pada penelitian ini adalah Aerator, Batang pengaduk, Cawan Porselen, 
Uji Toksisitas Ekstrak Etanol Umbi Talas (Colocasia esculenta L. Schoot) Dengan Metode Brine Shrimp Lethality Test Terhadap Artemia Salina Leach

Corong (Phyrex), Lampu, Labu takar, Mikropipet, Pipet skala, Pipet tetes, Seperangkat alat maserasi, Timbangan kasar (O'hauss), Timbangan analitik, Vial.

Bahan-bahan yang digunakan pada penelitian ini adalah air laut, air suling/aquadest, ekstrak etanol umbi talas (Colocasia esculenta L. Schott), etanol $70 \%$, larva udang (Artemia salina Leach), ragi dan vinkristin $1 \mathrm{mg}$.

\section{Prosedur Penelitian}

\section{Pembuatan sampel}

Sampel umbi talas (Colocasia esculenta L. Schott) yang telah dikeringkan ditimbang sebanyak 300 gram dimasukkan ke dalam wadah maserasi, lalu ditambahkan pelarut etanol $70 \%$ sebanyak $4.000 \mathrm{~mL}$ hingga simplisia tersebut terendam, dibiarkan selama 3 hari dalam bejana tertutup dan terlindungi dari cahaya matahari langsung sambil diaduk secara periodik, setelah $3 \times 24$ jam dilakukan penyaringan untuk diperoleh ekstrak etanol cair. Hasil penyarian yang diperoleh kemudian diuapkan dengan menggunakan rotavapor hingga diperoleh ekstrak kental.

\section{Penyiapan Hewan Uji}

Hewan uji yang digunakan dalam penelitian ini adalah Arthemia salina L. yang dipelihara dalam wadah yang berisi air laut bersih dengan $\mathrm{pH}$ yang dikondisikan 8,0-8,5 dibawah cahaya lampu dan suhu $28^{\circ} \mathrm{C}-30^{\circ} \mathrm{C}$, menggunakan aerasi kuat dari bawa tangki/tempatnya dan dibiarkan selama 48 jam.

\section{Perlakuan Terhadap Hewan Uji}

Ekstrak kental ditimbang sebanyak $200 \mathrm{mg}$ dilarutkan dengan etanol70\% $20 \mathrm{ml}$ sehingga diperoleh konsentrasi ekstrak $10 \mathrm{mg} / \mathrm{ml}$ sebagai larutan persediaan (stok). Dari sediaan tersebut dipipet $0,1,1,10,100,1000$, dan $10.000 \mu \mathrm{g} / \mathrm{ml}$ (ppm) kedalam vial, lalu diuapkan. Untuk pembanding yaitu obat vinkristin $1 \mathrm{mg}$ dilarutkan dengan air laut sebanyak $10 \mathrm{ml}$ sehingga diperoleh konsentrasi obat dalam air laut $0,1 \mathrm{mg} / \mathrm{ml}$ sebagai larutan stok, dari larutan stok dipipet 0,$01 ; 0,1 ; 1$ dan $10 \mu \mathrm{g} / \mathrm{ml}(\mathrm{ppm})$ dan untuk kontrol negatif yaitu air laut. Lalu dimasukkan 10 ekor larva udang Artemia, dan dicukupkan volumenya sampai $10 \mathrm{ml}$. tiap vial ditambahkan 1 tetes suspensi ekstrak ragi ( $3 \mathrm{mg}$ dalam $5 \mathrm{ml}$ air laut) sebagai sumber makanan. Vial-vial uji kemudian disimpan ketempat yang cukup mendapat sinar lampu. Setelah 24 jam dilakukan pengamatan terhadap jumlah larva yang mati. Untuk tiap sampel dan kontrol dilakukan pengulangan sebanyak 10 kali. 
Uji Toksisitas Ekstrak Etanol Umbi Talas (Colocasia esculenta L. Schoot) Dengan Metode Brine Shrimp Lethality Test Terhadap Artemia Salina Leach

\section{HASIL PENELITIAN}

Tabel 1. Data Hasil Pengamatan Kematian Larva Udang Artemia salina Leach selama 24 jam perlakuan.

\begin{tabular}{cccccccc}
\hline \multirow{2}{*}{ Jenis sampel } & \multicolumn{8}{c}{$\begin{array}{c}\text { Jumlah larva Artemia salina Leach yang mati tiap } \\
\text { konsentrasi }(\boldsymbol{\mu g} / \mathbf{m l})\end{array}$} & $\begin{array}{c}\text { Kontrol } \\
(-)\end{array}$ \\
\cline { 2 - 9 } & $\mathbf{0 , 1}$ & $\mathbf{1}$ & $\mathbf{1 0}$ & $\mathbf{1 0 0}$ & $\mathbf{1 . 0 0 0}$ & $\mathbf{1 0 . 0 0 0}$ & \\
\hline \multirow{3}{*}{ Ekstrak Etanol } & 3 & 4 & 4 & 5 & 8 & 9 & 0 \\
& 2 & 3 & 3 & 6 & 6 & 8 & 0 \\
\hline Total kematian & 3 & 3 & 3 & 4 & 6 & 9 & 0 \\
\hline$\%$ kematian & $26,67 \%$ & $33,33 \%$ & $33,33 \%$ & $50 \%$ & $66,67 \%$ & $86,67 \%$ & $0 \%$ \\
\hline
\end{tabular}

Tabel 2. Data Hasil Pengamatan Kematian Larva Udang Artemia salina Leach selama 24 jam perlakuan untuk vinkristin sebagai pembanding.

\begin{tabular}{ccccc}
\hline \multirow{2}{*}{$\begin{array}{c}\text { Sampel } \\
\text { Pembanding }\end{array}$} & \multicolumn{4}{c}{ Jumlah larva Artemia salina Leach yang mati tiap konsentrasi } \\
\cline { 2 - 5 } & $\mathbf{0 , 0 1}$ & $\mathbf{0 , 1}$ & $\mathbf{1} \mathbf{~})$ & $\mathbf{1 0}$ \\
\hline & 2 & 2 & 5 & 10 \\
& 1 & 3 & 4 & 10 \\
Ekstrak Etanol & 1 & 3 & 6 & 10 \\
& 1 & 3 & 5 & 10 \\
& 0 & 2 & 4 & 10 \\
& 1 & 2 & 5 & 10 \\
\hline Total kematian & 2 & 4 & 5 & 10 \\
\hline \% kematian & 8 & 19 & 34 & 70 \\
\hline
\end{tabular}

Tabel 3. Hasil perhitungan $\mathrm{LC}_{50}$ dengan menggunakan analisis probit terhadap ekstrak etanol Umbi Talas (Colocasia esculenta L. Schott) dan sampel pembanding (Vinkristin).

\begin{tabular}{ccc}
\hline No. & Sampel & LC $_{50} \pm$ Standar Eror \\
\hline 1. & Ekstrak Etanol Umbi Talas (Colocasia esculenta L. & $33,997 \pm 0,60$ \\
2. & Schott) & $0,398 \pm 0,946$ \\
\hline
\end{tabular}

\section{PEMBAHASAN}

Pada penelitian ini dilakukan pengujian toksisitas ekstrak etanol umbi talas (Colocasia esculenta $L$. Schoot) dengan metode Brine Shrimp Lethality Test, digunakan metode ini karena merupakan salah satu metode uji toksisitas yang banyak digunakan dalam penelusuran senyawa bioaktif yang bersifat toksik dari bahan alam. Metode ini dapat digunakan sebagai bioassay untuk fraksinasi dari bahan alam karena mudah, cepat, murah dan dapat dipercaya. Beberapa senyawa bioaktif yang telah berhasil diisolasi dan dimonitor aktivitasnya dengan 
Uji Toksisitas Ekstrak Etanol Umbi Talas (Colocasia esculenta L. Schoot) Dengan Metode Brine Shrimp Lethality Test Terhadap Artemia Salina Leach

Brine Shrimp Lethality Test menunjukkan adanya korelasi terhadap suatu uji spesifik antikanker.

Pengujian toksisitas pada penelitian ini dimaksudkan untuk mengamati efek toksisitas dan potensi antikanker pada ekstrak etanol umbi talas (Colocasia esculenta L. Schott) dengan melihat tingkat kematian Artemia salina Leach dan menentukan nilai LC $_{50}$ (Lethal Consentration 50). Aktivitas toksisitas berdasarkan $\mathrm{LC}_{50}$ yaitu $500-1000 \mu \mathrm{g} / \mathrm{ml}$ dianggap lemah (sedikit toksik), $\quad 100-500 \mu \mathrm{g} / \mathrm{ml}$ dianggap sedang (cukup toksik), 0-100 $\mu \mathrm{g} / \mathrm{ml}$ dianggap kuat (sangat toksik), $>1000 \mu \mathrm{g} / \mathrm{ml}$ dianggap tidak toksik (Nguta, et al., 2012).

Proses ekstraksi menggunakan metode maserasi dengan menggunakan pelarut etanol $70 \%$ yang bersifat semipolar dengan maksud untuk menarik komponenkomponen kimia yang ada dalam sampel tanaman baik yang bersifat polar dan non polar selain itu etanol tidak bersifat toksik.

Metode Maserasi digunakan karena metode ini termasuk metode yang paling sederhana dan menggunakan alat-alat yang sederhana pula, yang dilakukan dengan cara merendam serbuk dalam cairan penyari selama beberapa hari pada temperatur kamar dan terlindung dari cahaya.

Penggunaan aerator dalam penetasan larva udang dimaksudkan untuk membantu sirkulasi telur dan kadar $\mathrm{O}_{2}$ yang dibutuhkan dalam air. Pada waktu penetasan juga harus mendapatkan sinar lampu yang cukup ini dimaksudkan untuk merangsang penetasan telur. Pada proses penetasan, $\mathrm{pH}$ yang paling baik digunakan yaitu antara 8-9 dan apabila pada proses ini pHnya di bawah 5 atau lebih tinggi dari 10 maka akan membunuh Artemia salina.

Ekstrak etanol umbi talas dibuat dengan konsentrasi $0,1,10,100,1000$, dan $10000 \mu \mathrm{g} / \mathrm{ml}$ ini dimaksudkan untuk melihat variasi respon yang diberikan. Diujikan pada hewan uji larva udang Artemia salina Leach berumur 48 jam, karena pada umur tersebut Artemia salina Leach mengalami pertumbuhan yang cepat sehingga dianalogikan sebagai pertumbuhan sel yang abnormal.

Pembanding air laut dimaksudkan untuk melihat apakah respon kematian hewan uji benarbenar berasal dari sampel dan bukan disebabkan oleh faktor teknis perlakuan.

Sebanyak masing-masing 10 ekor larva udang untuk tiap 
Uji Toksisitas Ekstrak Etanol Umbi Talas (Colocasia esculenta L. Schoot) Dengan Metode Brine Shrimp Lethality Test Terhadap Artemia Salina Leach

konsentrasi, sampel diujikan dengan parameter kematian setelah 24 jam dan diulang sebanyak 3 kali. Kemudian tiap vial diberikan 1 tetes ekstrak ragi yang merupakan salah satu sumber nutrisi pada Artemia salina Leach (Mudjiman, 1989). Pemberian makanan dilakukan pada saat pengujian (larva usia 48 jam).

Pada penelitian ini digunakan obat vincristine sebagai pembanding dengan variasi konsentrasi yaitu 0,01 , $0,1, \quad 1$, dan $10 \mu \mathrm{g} / \mathrm{ml}$, untuk menunjukkan aktivitas toksisitas yang sebanding dengan ekstrak uji atau tidak dalam range yang dianggap kuat. Untuk melihat perbandingannya, digunakan aktivitas toksisitas dari siklophosphamide yaitu dengan nilai $\mathrm{LC}_{50}$ yaitu $6 \mu \mathrm{g} / \mathrm{ml}-95 \mu \mathrm{g} / \mathrm{ml}$ yang dianggap sangat kuat.

Setelah 24 jam perlakuan, dihitung jumlah larva Artemia salina Leach yang mati dari setiap vial, dilakukan perlakuan yang sama terhadap pembanding. Hasil penelitian diperoleh jumlah larva udang yang mati pada konsentrasi $0,1 \mu \mathrm{g} / \mathrm{ml}$ sebanyak 26,67\%, $1 \mu \mathrm{g} / \mathrm{ml}$ sebanyak $33,33 \%, 10 \mu \mathrm{g} / \mathrm{ml}$ sebanyak $33,33 \%$, $100 \mu \mathrm{g} / \mathrm{ml}$ sebanyak $50 \%, 1000 \mu \mathrm{g} / \mathrm{ml}$ sebanyak 66,67\%, $10000 \mu \mathrm{g} / \mathrm{ml}$ sebanyak $86,67 \%$ dan kontrol air laut sebanyak $0 \%$. Dilihat dari perolehan persentase kematian Artemia, konsentrasi ekstrak yang paling baik dalam membunuh Artemia yaitu pada konsentrasi $100 \mu \mathrm{g} / \mathrm{ml}$, sedangkan konsentrasi vinkristin yang paling baik dalam membunuh Artemia yaitu pada konsentrasi $1 \mu \mathrm{g} / \mathrm{ml}$. Kemudian data dari ekstrak etanol umbi talas (Colocasia esculenta L.schott) dan vinkristin dihitung nilai $\mathrm{LC}_{50}$ dengan menggunakan metode grafik probit log konsentrasi.

Hasil dari analisis probit dengan menunjukkan $\mathrm{LC}_{50}$ dari ekstrak etanol umbi talas (Colocasia esculenta L.schott) dengan tingkat kepercayaan $95 \%$ yaitu $33,997 \mu \mathrm{g} / \mathrm{ml}(7,970 \mu \mathrm{g} / \mathrm{ml}-$ $151,231 \mu \mathrm{g} / \mathrm{ml})$. Hasil data dari pembanding obat vinkristin menunjukkan nilai $L_{50}$ yaitu 0,398 $\mu \mathrm{g} / \mathrm{ml} \quad(0,259 \mu \mathrm{g} / \mathrm{ml}-0,624 \mu \mathrm{g} / \mathrm{ml})$. Berdasarkan kategori aktivitas toksisitas nilai $\mathrm{LC}_{50}$ yang diperoleh termasuk dalam kategori toksisitas 0$100 \mu \mathrm{g} / \mathrm{ml}$ dianggap kategori kuat dan menunjukkan bahwa ekstrak etanol umbi talas (Colocasia esculenta L.schott) bersifat toksik terhadap Artemia salina Leach.

Suatu sampel dapat dikatakan memiliki potensi sebagai antikanker apabila uji toksisitas dengan $\mathrm{LC}_{50}<1000 \mu \mathrm{g} / \mathrm{ml}$ (Meyer, 1982) dan jika semakin kecil nilai $L_{50}$ dari 
Uji Toksisitas Ekstrak Etanol Umbi Talas (Colocasia esculenta L. Schoot) Dengan Metode Brine Shrimp Lethality Test Terhadap Artemia Salina Leach

ekstrak uji maka sampel uji memiliki aktivitas sebagai antikanker (Lisdawati, 2006). Hasil penelitian yang menunjukkan nilai $\mathrm{LC}_{50}$ termasuk dalam kategori aktivitas toksisitas yang dianggap kuat dan dapat berpotensi besar sebagai antikanker sehingga bisa dilakukan penelitian lebih lanjut terhadap sampel uji.

\section{KESIMPULAN}

Berdasarkan hasil penelitian dapat disimpulkan bahwa ekstrak etanol umbi talas (Colocasia esculenta L.schott) bersifat toksik karena memiliki nilai $\mathrm{LC}_{50}<1000 \mu \mathrm{g} / \mathrm{mL}$ yaitu sebesar 33,997 $\mu \mathrm{g} / \mathrm{ml} \quad(7,970 \mu \mathrm{g} / \mathrm{ml}$ $151,231 \mu \mathrm{g} / \mathrm{ml}$ ) sedangkan nilai LC $_{50}$ obat vincristine yaitu sebesar 0,398 $\mu \mathrm{g} / \mathrm{ml}(0,259 \mu \mathrm{g} / \mathrm{ml}-0,624 \mu \mathrm{g} / \mathrm{ml})$. Jadi ekstrak etanol umbi talas (Colocasia esculenta L.schott) memiliki toksisitas akut yang berpotensi sebagai antikanker.

\section{DAFTAR PUSTAKA}

Angelin, D.F., Karim, A., Asmawati., dan Seniwati. 2012. Analisis Kandungan $\beta$-Karoten Dan Vitamin C Pada Berbagai Varietas Talas (Colocasia esculenta). Jurusan Kimia Fakultas MIPA Universitas Hasanuddin, Makassar
Farida, Y., Martati,T., Musir.,A., Edward,B. $2010 . \quad$ Uji Sitotoksik Dan Antioksidan Dari Ekstrak Daun Keladi Tikus (Typhonium divaricatum (L) Decne). Fakultas Farmasi Universitas Pancasila, Jagakarsa Jakarta.

Lisdawati V., wiryowidagdo S., Kardono L.B.S., 2006. Brine Shrimp Lethality Test (BSLT) dari Berbagai Fraksi Ekstrak Daging Buah dan Kulit Biji Mahkota Dewa (Phaleria marcocarpa). Pusat Penelitian Kimia, Puspiptek LIP1 Vol 34 no 3.(Online), (http://ejournal.litbang.depke s.go.id/index.php/BPK/article /viewFile/1208/130) (Diakses dimakassar 6 februari 2014).

Meyer, B. N., Ferrigni, N. R., Putman, J. E., Jacbsen, L. B., Nicols, D. E., and McLaughlin, J. L. 1982. Brine Shrimp : $A$ Comvenient general Bioassay For Active Plant Constituents. Plant Medica.

Mudjiman, A. 1989. Udang Renik Air Asin. Brata Karya Aksara, Jakarta.

Nguta, J.M., Mbaria, J.M., Gakuya, D.M., Gathumbi, P.K., Kabasa, J.D., and Kiama, S.G. 2012. Evaluation of Acute Toxicity of Crude Plant Extracts From Kenyan Biodiversity Using Brine Shrimp, Artemia salina $L$. Vol 3 : $30-34$ 